Journal of Tropical Industrial Agriculture
and Rural Development

\title{
Manipulation of microhabitat by polyculture planting system as ecosystem stabilizer for management of pests and natural enemies in shallot (Allium ascalonicum Linn.)
}

\author{
Sigit Prastowo ${ }^{1^{*}}$ and Rizal Sukarno ${ }^{2}$ \\ ${ }^{1}$ Department of Plant Protection, Faculty of Agriculture, University of Jember, Jl. Kalimantan 37 Bumi Kampus Tegal \\ Boto Jember, East Java Indonesia, 68121 \\ ${ }^{2}$ Agrotechnology Study Program, Faculty of Agriculture, University of Jember, Jl. Kalimantan 37 Bumi Kampus Tegal \\ Boto Jember, East Java Indonesia, 68121
}

\begin{abstract}
Shallot (Allium ascalonicum Linn.) is one of important commodities for Indonesian people, yet its production is still limited by pest attack This research was conducted in Banyuputih Village, Wringin Subdistrict, Bondowoso Regency from July to October 2019. This study applied a Randomized Block Design (RBD) with six treatments, namely: P1 = Polyculture of shallot + lemongrass; P2 = Polyculture of shallot + celery; P3 = Polyculture of shallot + mustard; P4 = Polyculture of shallot + lemongrass + mustard; P5 = Polyculture of shallot + celery + mustard; P6 = Monoculture of shallot. Each treatment was repeated 4 times. Observation was started when plant was at the age of 30 days after planting. Data collection was done by directly observing the sample plants. Sampling was carried out using Yellow trap and pit fall trap. A total of 10 samples were collected from each plot with interval of 4 days. Observation included collecting the pest insects and natural enemies that were found, counting the number of populations of each species, and scoring towards the damage plants. The results showed that shallot planting by polyculture with different types of plants affected the population of pests and natural enemies as well as the level of diversity of insects in shallots. Planting shallots by polyculture has been proven to control pest population compared to planting shallots by monoculture. Polyculture planting with two types of plants was found to produce better outcome than polyculture planting with three types of plants with best treatment observed in P1, namely polyculture of shallot and lemongrass which resulted in the lowest pest population of 17.5 .
\end{abstract}

Keywords: Shallot, Manipulation, Polyculture.

\section{INTRODUCTION}

Shallot (Allium ascalonicum Linn.) is one of commodities considered important for the society, both in term of economy and nutrition. Many factors have been identified to cause harvest failure in shallot farming, such as pest attack. Several pests often attack shallot, such as Spodoptera exigua, Spodoptera litura, and Liriomyza huidobrensis. S. exigua is the major pest in shallot production center. This pest could 
decrease production output up to $75 \%$ in the absence of pest control since this species is a polyfag (Haryati and Nurawan, 2009). Farmers normally conduct pest control using synthetic pesticide since it is considered effective to kill pest. However, various negative impacts due to continuous use of synthetic pesticide use, namely pest resistance and resurgence, death of natural enemy, and accumulation of chemical materials that sre harmful to health and damage the environment (Harun et al., 1996).

Putro (2016) mentioned that ecosystem diversity could be used to facilitate pest and disease control. One effort to improve ecosystem diversity can be achieved through cropping/ planting system management. According to Sjam et al, (2011), polyculture planting system is one solution to enhance production and prevent harvest failure. Lamba (2017) proved that polyculture planting of shallot and lemongrass could increase production of 18,5 ton/ha. Based on the background formerly explained, it is necessary to conduct study about "Manipulation of Microhabitat by Polyculture Planting System as Ecosystem Stabilizer for Management of Pests and Natural Enemies in Shallot".

\section{MATERIAL AND METHOD}

\section{Experimental design}

This study was conducted in from July to October 2019 in Banyuputih Village, Wringin Subdistrict, Bondowoso Regency. This study applied a Randomized Block Design (RBD) with one factor, that is number of plant in polyculture system, namely: P1 = Polyculture of shallot + lemongrass; P2 = Polyculture of shallot + celery; P3 $=$ Polyculture of shallot + mustard; $\mathrm{P} 4=$ Polyculture of shallot + lemongrass + mustard; P5 $=$ Polyculture of shallot + celery + mustard; P6 = Monoculture of shallot. Each treatment was repeated 4 times.

\section{Land preparation}

Land preparation included land clearing, land cultivation, and experimental plot making. Experimental field consisted of 24 plots with planting plot size of $2 \times 1 \mathrm{~m}$. Planting distance between plots was 1 meter and bordered by plastic barrier, resulted in a total plot area of $7 \times 17 \mathrm{~m}$. Land clearing conducted were weeding and plant residue clearing. Later, minimum tillage was performed gently using hoe.

\section{Planting}

Shallot was planted simultaneously with other crops, except lemongrass that has been grown 4 weeks before planting period. Planting distance of $30 \mathrm{~cm} \times 20 \mathrm{~cm}$ was applied, thus each plot consisted of 28 plants. Crops planted by polyculture were grown around the edge of the main crop (Shallot) with composition: P1: Polyculture of shallot + lemongrass (14 : 14); P2 : Polyculture of shallot + celery (14:14); P3 : Polyculture of shallot + mustard (14 : 14); P4 : Polyculture of shallot + lemongrass + celery (14:7 : 7); P5 : Polyculture of shallot + lemongrass + mustard (14: $7: 7)$; P6 : Monoculture of shallot as control..

\section{Plant maintenance}

Plant maintenance consisted of fertilizing, weeding, watering, and replacement. Fertilizing was done 3 times, namely fertilizing using basic fertilizer such as manure and TSP/SP-36 fertilizer of $0,5 \mathrm{~kg} / \mathrm{plot} 3$ days before planting, supplementary fertilizing I when plant reached the age of $15 \mathrm{DAP}$, and supplementary fertilizing II at the age of 30 DAP, for $1 / 2$ dosage of each. Weeding was intensively performed in the beginning of planting period until crops were 2 weeks of age. Watering was carried out two times a day with moderate water intensity. Replacement was conducted only when plants were found dead or grew poorly.

\section{Harvesting}

Harvesting was done when plants reached 70 days of age after planting. Shallots are ready to be harvested if $60 \%$ of the stem neck is already soft, plants start to wither, and leaves turn yellow.

\section{Variable of observation}

Species of Pest and Natural Enemy and Their Population. Observation of pest insects and natural enemy insects was done directly by visual control method. Observation was started since plants reached the age of $30 \mathrm{DAP}$ with interval of 4 days. Sampling was conducted through the method of pit fall trap and yellow trap. Pest and 
natural enemy insects collected were further identified and calculated for their population.

\section{Intensity of plant damage}

Plant damage in shallot was directly observed by investigating the symptoms caused by pest attack. Samples observed were all units of experiment. Observation was performed when plants reached the age of $60 \mathrm{DAP}$. Intensity of shallot damage was observed by determining the percentage (\%) of plant attacked using the formula below (Lamba et al., 2017):

Description:

$$
\mathrm{P}=\frac{\mathrm{n}}{\mathrm{N}} \mathrm{X} 100 \%
$$

$\mathrm{P}=$ Percentage of attack

$\mathrm{n}=$ Total of plant parts attacked

$\mathrm{N}=$ Total of plant parts observed

Diversity Index. Diversity of pests and natural enemies was measured using the formula of diversity index introduced by Shanon-weiner. According to Fachrul (2007), the formula for Shanon-weiner diversity index is written as follow

Description:

$$
\mathrm{H}^{\prime}=-\sum \mathrm{Pi} \cdot \ln \mathrm{Pi}
$$

H' = Diversity Index

$\mathrm{Pi}=$ Proportion of individual in species $\mathrm{i}$

$\mathrm{n}=$ Total number of individual in species $\mathrm{i}$

$\mathrm{N}=$ Total number of individual

\section{RESULT DAN DISCUSSION}

\section{Population of pest insects in shallot}

Result of observation and identification showed five pest species collected, namely $T$. tabacci, $L$. huidobrensis, Gryllotalpa, S. litura, S. exigua, and A. ipsilon (Figure 1). Result of ANOVA indicated that the highest total population of pest was found in P6 (control), P3, P4, and P5, respectively, those were $30.75,30.25,26.0$, and 26.0 , while the lowest population was obtained by $\mathrm{P} 1$ of 17.5 and treatment 2 of 19.75 (Table 1).

Population level of pest obtained in this study showed that planting by polyculture with two types of plant ( $\mathrm{P} 1$ and $\mathrm{P} 2)$ was better than polyculture with 3 types of plant (P4 and $\mathrm{P} 5)$ and control (P6), except for P3. Treatment P3 (polyculture of shallot and mustard) generated a population that was not significantly different from control as they are also shallot pest hosts. The highest population of T. tabacci and S. exigua pests was found in P6, while the lowest population was obtained by P1. Post hoc test performed on $L$. huidobrensis population resulted in a nonsignificantly different value since the population observed was considered too low.

The highest population of $S$. exigua pest was found in P6 or monoculture treatment (control). Moreover, the highest population of S. litura and A. ipsilon pests was obtained in P3, yet the lowest population of $S$. litura was found in $\mathrm{P} 1$ and $\mathrm{P} 4$, while the lowest population of $A$. ipsilon was found in P2, namely polyculture of shallot and celery (Table 1). High population in P3 was caused by the fact that mustard is also host plant for pests that attack shallot (Kurniawan, 2018).

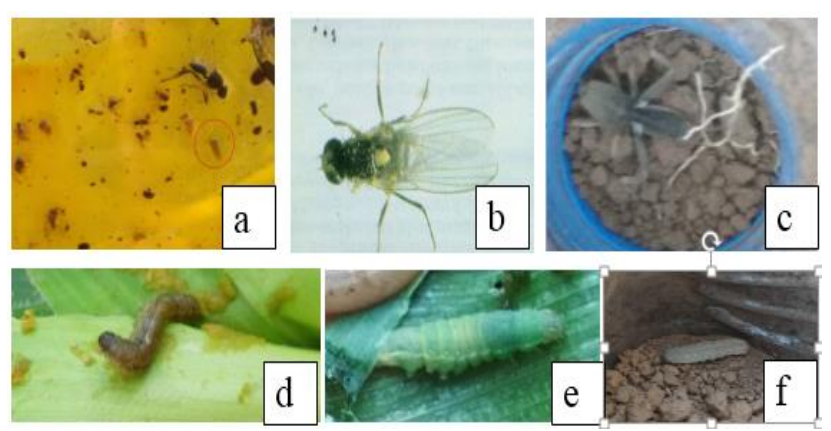

Figure 1. (a) T. tabacci; (b) L. huidobrensis; (c) Gryllotalpa; (d) S. litura; (e) S. exigua; and (f) A. ipsilon.

\begin{tabular}{|c|c|c|c|c|c|c|}
\hline \multirow{2}{*}{ Treatment } & \multirow{2}{*}{ Total } & \multicolumn{5}{|c|}{ Average population of each pest species (individual pest) } \\
\hline & & T. tabacci & S. exigua & L. huidobrensis & S. litura & A. ipsilon \\
\hline P1 & $17.5 \mathrm{~b}$ & $8.75 \mathrm{c}$ & $4.25 \mathrm{c}$ & $1.75 \mathrm{a}$ & $1.5 \mathrm{~b}$ & $1 \mathrm{a}$ \\
\hline $\mathrm{P} 2$ & $19.75 b$ & $9.75 \mathrm{c}$ & $5.75 \mathrm{bc}$ & $2.5 \mathrm{a}$ & $1.75 \mathrm{~b}$ & $0 \mathrm{~b}$ \\
\hline P3 & $30.25 \mathrm{a}$ & $14 \mathrm{ab}$ & $7.5 \mathrm{~b}$ & $2.25 \mathrm{a}$ & $3 a$ & $1.25 \mathrm{a}$ \\
\hline $\mathrm{P} 4$ & $26.0 \mathrm{ab}$ & $14.25 \mathrm{ab}$ & $5.75 b$ & $1.75 \mathrm{a}$ & $1.5 \mathrm{~b}$ & $0.25 \mathrm{a}$ \\
\hline P5 & $26.0 \mathrm{ab}$ & $13.5 \mathrm{~b}$ & $6.75 \mathrm{~b}$ & $1.5 \mathrm{a}$ & $2.75 \mathrm{a}$ & $0.5 \mathrm{~b}$ \\
\hline $\mathrm{P} 6$ & $30.75 \mathrm{a}$ & $16.5 \mathrm{a}$ & $10.0 \mathrm{a}$ & $2.5 \mathrm{a}$ & $2.0 \mathrm{~b}$ & $0.25 \mathrm{~b}$ \\
\hline
\end{tabular}

Table 1. Population of pest species (Plant) 


\section{Population of natural enemy insects in shallot.}

Observation result indicated that 5 species of 4 order of natural enemy insect caught in the trap were Chilomenes sexmaculatus, Ceolophora pupillata, Eriborus argenteopilosus, Lycosa sp, and Gynaccantha subterrupta (Figure 2). The highest population level of natural enemy obtained by $C$. sexmaculatus and $C$. pupillata which belong to family Coccinelidae was $29.8 \%$. The value was followed by E. argenteopilosus of $18.3 \%$, Lycosa sp. of $17.3 \%$ and G. subterupta of $4.8 \%$. Treatment of planting by polyculture with several different types of plant significantly affected the population of natural enemy. Result of ANOVA showed that the highest and the lowest total population of natural enemy was found in P3 and P1, respectively.

Total population of natural enemy indicated that treatment of polyculture with mustard (P3) was able to increase the number of natural enemy, but treatment with the two other plants (Lemongrass and Celery) resulted in the lowest population since they are repellent plants.

Polyculture with three types of plant ( $\mathrm{P} 4$ and P5) resulted in higher population compared with polyculture with two types of plant (P1 and P2) and control (P6).
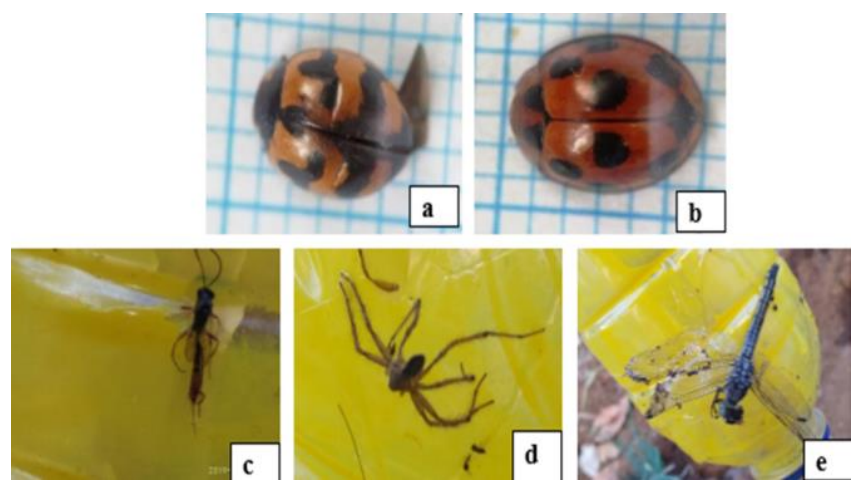

Figure 2. (a) C. sexmaculatus, (b) C. pupillata, (c) E. argenteopilosus, (d) Lycosa sp. and (e) G. subterupta
Moreover, population of C. sexmaculatus and E. argenteopilosus was found in P3 (polyculture of shallot and mustard). The highest population of $C$. pupillata was found in P5 and the lowest was in P4. The highest population of Lycosa sp. was found in P4 and the lowest was found in P2 (Table 2).

\section{Intensity of plant damage}

The highest intensity of pest attack was found in P6 and P3 of 24.51 and 22.63, respectively, followed by P5, P4, P2 and P1 of respectively 20.93 , $20.74,20.63$ and 20.12 , yet all values were not significantly different in post hoc test. This result showed that planting by polyculture with two types of plant (P1 and P2) was considered better to suppress pest attack than polyculture with three types of plant (P4 and P5) and control (P), except for P3 or polyculture of shallot and mustard which was also found to be the same host for pests that attacked plants (Figure 3).

Diversity Index of Insects. The value of diversity index of pest natural enemy insects found was calculated using Shanon-weiner formula. Analysis result of diversity index using the formula of Shanon-Weiner Index showed species abundance. According to Fachrul (2007), H' = $1 \leq$ $\mathrm{H}^{\prime} \leq 3$ indicates abundant diversity.

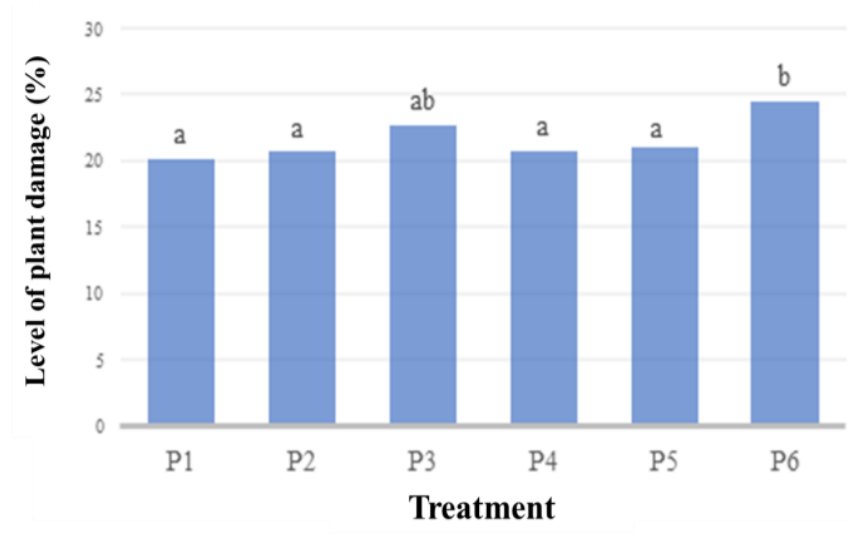

Figure 3. The level of plant damage (plant)

Table 2. Population of natural enemy species (Plant)

\begin{tabular}{cccccc}
\hline \multirow{2}{*}{ Treatment } & \multirow{2}{*}{ Total Natural Enemy } & \multicolumn{4}{c}{ Average Population of Natural Enemy (individual animal) } \\
\cline { 2 - 6 } & & C. sexmaculatus & C. pupillata & E. argenteopilosus & Lycosa sp. \\
\hline P1 & $1.75 \mathrm{~d}$ & $0 \mathrm{~d}$ & $1 \mathrm{ab}$ & $0 \mathrm{bc}$ & $0.75 \mathrm{~b}$ \\
P2 & $2.75 \mathrm{~cd}$ & $0.75 \mathrm{~cd}$ & $1.25 \mathrm{a}$ & $0.75 \mathrm{~b}$ & $0 \mathrm{c}$ \\
P3 & $8.75 \mathrm{a}$ & $3.25 \mathrm{a}$ & $1.75 \mathrm{a}$ & $2 \mathrm{a}$ & $1.25 \mathrm{ab}$ \\
P4 & $4.25 \mathrm{bc}$ & $1.25 \mathrm{c}$ & $0 \mathrm{~b}$ & $1.5 \mathrm{ab}$ & $1.5 \mathrm{a}$ \\
P5 & $5.25 \mathrm{~b}$ & $2.5 \mathrm{~b}$ & $2 \mathrm{a}$ & $0 \mathrm{bc}$ & $0.25 \mathrm{bc}$ \\
P6 & $3 \mathrm{c}$ & $0 \mathrm{~d}$ & $1.75 \mathrm{a}$ & $0.5 \mathrm{~b}$ & $0.75 \mathrm{~b}$ \\
\hline
\end{tabular}


Table 3. Diversity index of insects (Shanon-Weiner)

\begin{tabular}{cc}
\hline Treatment & $\mathrm{H}^{\prime}$ \\
\hline P1 & 2.03 \\
P2 & 2.25 \\
P3 & 2.88 \\
P4 & 2.29 \\
P5 & 2.31 \\
P6 & 2.19 \\
\hline
\end{tabular}

Base on the Table 3, the highest diversity index was found in P3 or polyculture of shallot + mustard of 2.88 which was followed by P5 and P4 respectively of 2.31 and 2.29 where both treatments were also polyculture of three types of plant. Later, diversity in P2 and P1 (polyculture of two types of plant) was measured to reach 2.25 and 2.13, respectively. The lowest diversity was obtained in P6 or monoculture of shallot which only amounted to 2.19 . This finding proved that polyculture of shallot and mustard significantly increased diversity level.

As observed from plant number, treatment of Polyculture with three types of plant (P5 and P4) was better to increase diversity compared to polyculture with two types of plant (P2 and $\mathrm{P} 1)$, while Monoculture (Control) poorly increased insect diversity.

Result of observation and identification revealed several species of pests found in research location. Most pest species collected were pest that attack leaves. There were five species caught in this study, namely $T$. tabacci, S. exigua, $L$. huidobrensis, S. litura, A. ipsilon and Gryllotalpa sp. Moreover, T. tabacci was found to be species with the highest population of $51 \%$, followed by $S$. exigua of $28 \%$, L. huidobrensis and S. litura of $9 \%$ of each, A. ipsilon of $2 \%$, and Gryllotalpa of $1 \%$.

Treatment of planting by polyculture with different number of plants affected the population of pest caught. Treatment P1 (polyculture of shallot + lemongrass) and P2 (polyculture of shallot + celery) was found to be the best treatment to control pest population. Treatment P1 and P2 proved that planting by polyculture with two types of plant could significantly suppress pest population compared with polyculture with three types of plant.

Treatment $\mathrm{P} 1$ and $\mathrm{P} 2$ were better to control pest population since both treatments were polyculture of shallot and repellent plants. Tuetun et al. (2008) reported that celeries contain 3-n-butyltetrahydrophthalide $(92.48 \%)$, beta-selinene
(5.10\%), and gamma-selinene (0.68\%) which have properties to repel pests like mosquito and $T$. tabacci. According to Lamba et al. (2017), Treatment of Lemongrass Planting (PTS) 4 weeks before shallot planting could control the population of imago L. huidobrensis compared to PTS 2 and 0 week, also without lemongrass (control) in observation on 5 and 6 WAP.

Pest population in treatment P3 was extremely high even though P3 was polyculture of two types of plant which was similar to $\mathrm{P} 1$ and $\mathrm{P} 2$. Treatment P3 was polyculture of shallot and mustard, but mustard is host for pest insect that attacks shallot. P4 and P5 were polyculture with three types of plant. Observation result of pest population showed that polyculture with three types of plant was less effective to control pest population.

Treatment of polyculture of several types of plant affected population level of each pest species. Species T.tabacci was found the least in $\mathrm{P} 1$ and $\mathrm{P} 2$. Treatment P1 (shallot + lemongrass) and P2 (shallot + celery) could control population of $T$. tabacci since lemongrass and celery are repellent plants for pest. Species S. exigua was mostly found in treatment 6 or control, i.e. monoculture of shallot. According to Nelly et al. (2015), shallot planting by polyculture was able to decrease worm attack in shallot leaves. This shows that shallot planting by monoculture was not effective in controlling $S$. exigua pest. The second largest population of S. exigua was found in treatment P3 (polyculture of shallot and mustard) and P5 (polyculture of shallot, mustard, and lemongrass). In this treatment, mustard was expected to be the host for $S$. exigua which resulted in a very high population.

Result of post hoc test on population level of $L$. huidobrensis indicated that treatment applied was not significantly different since population of $L$. huidobrensis found during study was considered too low. However, average population level of $L$. huidobrensis was found to be the lowest in $\mathrm{P} 1$ and P5 due to the existence of lemongrass as pest repellent. According to Lamba et al. (2017), Treatment of Lemongrass Planting (PTS) 4 weeks before shallot planting could suppress the population of imago L. huidobrensis compared to PTS 2 and 0 week and without lemongrass (control) in observation 5 and 6 WAP.

Observation result showed that the highest population of $S$. litura was obtained in Treatment 3 or polyculture of shallot and mustard where 
mustard is also the host plant for S. litura besides shallot (Kurniawan, 2018). The second highest population level of $S$. litura was found in P5 (Polyculture of shallot, mustard, and lemongrass). Similar to treatment P3, pest population in treatment P5 was also high due to the existence of mustard as the host plant. The same result was found in A. ipsilon population as this species is also pest for mustard. The highest population in treatment of Polyculture of shallot and mustard (P3) and polyculture of shallot, mustard, and lemongrass (P5). According to Badan Penelitian dan Pengembangan Pertanian (2012), black cutworm may attack young mustard as indicated by fallen plants or leaves stalk (petiole) due to broken base of plant. Moreover, population of A. ipsilon was not found in treatment 2 (polyculture of shallot and celery). Tuetun et al. (2008) reported that celeries contain 3-n-butyl-tetrahydrophthalide (92.48\%), beta-selinene (5.10\%), and gamma-selinene (0.68\%) which functions as pest repellent.

Result of observation showed that 5 species which belonged to 4 order of natural enemy insects were caught in the trap, namely $C$. sexmaculatus, C. pupillata, G. subterrupta., Lycosa sp., and E. argenteopilosus. The highest population level of natural enemy was obtained by $C$. sexmaculatus and C. pupillata. from family Coccinelidae of 29.8 $\%$, followed by $E$. argenteopilosus of $18.3 \%$, Lycosa sp. of $17.3 \%$ and $G$. subterupta. of $4.8 \%$. Treatment of planting by polyculture with several different plants significantly affected the population of natural enemy. The highest population of natural enemy was found in treatment P3 (polyculture of shallot and mustard). Natural enemy insects found in this study were dominated by species from family Cocconelidae, namely $C$. sexmaculatus and C. pupillata (Borror et al., 1998). According to Efendi et al. (2016), habitat for most insects from family Coccinilidae includes broadleaved plants such as mustard. Borror et al. (1998) mentioned that major difference of each insect species in family Coccinilidae is spots on their body. Species C. sexmaculatus has black spots connected from the left side to the right side of the body (Figure 2a). Later, C. pupillata has symmetric small spots like pupil on both left and right side of the body (Figure $2 b$ ).

Imago parasitoids $E$. argenteopilosus has a black thorax and reddish brown abdomen. Female parasitoids are characterized by a relatively long ovipositor (Figure 2c). Normally, female parasi- toids are larger in size than males. Body length and wing span of female imago respectively are 7.0-8.0 $\mathrm{mm}$ and $11.0-13.0 \mathrm{~mm}$, while male imago are $5.5-8.5 \mathrm{~mm}$ and $9.0-12.0 \mathrm{~mm}$, respectively (Othman 1982). E. argenteopilosus is a natural enemy that attacks $S$. litura larvae, while $S$. litura is pest that attacks leave of shallot and mustard (Badan Penelitian dan Pengembangan Pertanian, 2012). In this study, the highest population of $E$. argenteopilosus was found in treatment 3 or polyculture of shallot and mustard.

Lycosa sp. is a type of predator spider that preys on S. litura larvae (Badan Penelitian dan Pengembangan Pertanian, 2012). The highest population of S. litura was found in treatment 3 or polyculture of shallot and mustard that is a host plant for armyworm caterpillar. Lycosa sp. is a type of predator spider with characteristics of larger body and blackish brown body color (Figure 2d) (Gavarra and Raros, 1975). G. subterrupta is a type of predatory dragonfly with characteristics of larger body compared to other dragonflies, blue head and stomach, and often found in rice fields. This dragonfly is quite big and dominated by green and brown color with blue spot on the abdomen (Kamaludin et al., 2016).

Result of diversity index measured using the formula of Shanon-Weiner Index showed that diversity level was abundant. According to Fachrul (2007), $\mathrm{H}^{\prime}=1 \leq \mathrm{H}^{\prime} \leq 3$ means species abundance in an area. The highest diversity index was found in treatment 3 , that was polyculture of shallot and mustard of 2.88. Shallot and mustard are plant hosts for the same pests. Hence, the highest pest population was obtained in this treatment. Moreover, population of natural enemy in this treatment was still considered high.

High population of pest indicates poor habitat that support plants. However, high population level of pest is expected to be controlled by natural enemy, thus resulting in high diversity in planting. The higher diversity index in a planting community, the higher the level of interaction between the member of community, such as energy transfer interaction, competition, predation, and space-sharing which theoretically will be more complex. Pelawi (2009) mentioned that higher diversity index reflects a more heterogeneous components of a community, thus lead to a more stable community.

The next highest diversity level was found in treatment $\mathrm{P} 5$ and $\mathrm{P} 4$ of 2.31 and 2.29, respectively. This result showed that polyculture with three 
plants was better to increase diversity level. Further, diversity level of $\mathrm{P} 2$ and $\mathrm{P} 1$ reached 2.25 and 2.23, while treatment P6 or control obtained the lowest diversity index of 2.19. This indicated that shallot planting by polyculture was better than that by monoculture considering the increasing diversity of insects.

Pests that attack shallot are mostly pests which attack leaves. Thus, the level of pest attack was observed by investigating leaf damage intensity due to pest attack. Damage intensity caused by pest attack was significantly different in some treatments. Treatment 6 or control, that is monoculture of shallot obtained the highest level of intensity of $24.51 \%$. Thus, it is assumed that shallot planting by polyculture could decrease pest attack intensity compared to planting by monoculture. This outcome is directly proportional to the population level of pest found where the highest pest population was found in treatment 6 or control. Treatment P3 (polyculture of shallot and mustard) ranked second in term of damage intensity, yet the result was not significantly different from control. Mustard is host plant for pest in shallot, such as T. tabacci, S. exigua and $L$. huidobrensis. Thus, pest attack level in polyculture of shallot and mustard was also high (Kurniawan, 2018).

Moreover, treatment P5, P4, P2, and P1 respectively obtained level of damage, from the highest to the lowest, despite the non-significant different result in DMRT post hoc test $5 \%$. Therefore, it is concluded that shallot planting by polyculture was able to decrease pest attack intensity compared to planting by monoculture. Furthermore, shallot planting by polyculture with 2 types of plant (P1 and $\mathrm{P} 2$ ) was better to decrease pest attack intensity compared to polyculture with 3 types of plant (P4 and P5), regardless of the nonsignificant different result.

Considering the plant type, treatment $\mathrm{P} 1$ was the best treatment in controlling pest attack intensity which reached $20.25 \%$. Treatment P1 was polyculture of shallot and lemongrass in which lemongrass is repellent plant for pests that attack shallot. Pinem (2005) mentioned that intercropping of potato and lemongrass was able to quite effectively suppress the population of $L$. huidobrensis pest. According to Widodo (2007), citronellal in lemongrass has pest repellent properties. Study conducted by Lamba et al. (2017) showed that intercropping of shallot and lemongrass successfully controlled the population of $L$. huidobrensis pest in shallot. Treatment of lemongrass planting (PTS) 4 weeks before shallot planting could suppress the population of $L$. huidobrensis compared to PTS 2 and 0 week before planting.

\section{REFERENCES}

Badan Penelitian dan Pengembangan Pertanian. 2012. Mengenal Organisme Pengganggu Tumbuhan (Opt) Bawang Merah Dan Musuh Alaminya. Jakarta (ID): Kementerian Pertanian.

Borror DJ, CA Triplehorn, NF Johnson. 1998. Pengenalan Pelajaran Serangga. Edisi ke Enam. Translated by Soetiyono Patosoedjono. 1992. Yogyakarta (ID): Gadjah Mada University Press.

Fachrul MF. 2007. Metode Sampling Bioekologi. Jakarta (ID): Bumi Aksara.

Gavarra MR, RS. Raros. 1975. Studies on the biology of the predatory wolf spider, Lycosa pseudoannulata Boes. et Str. (Araneae: Lycosidae). Philipp. Ent. 2(6): 427-444.

Harun S, P Wasil, S Agus. 1996. In Indraningsih, Y Sani, R Widastuti, E Masbulan, M Dianawati. Pengendalian Kontaminan Pestisida di Lingkungan Pertanian dan Peternakan

Haryati Y, A Nurawan. 2009. Peluang pengembangan feromon seks dalam pengendalian hama ulat bawang (Spodoptera exigua) pada bawang merah. Jurnal Penelitian dan Pengembangan Pertanian 28(2): 72-78.

Kamaludin N, DW Pamungkas, A Nugrahaningrum, WS Rahadi. 2016. Mengungkap Potensi Hulu Bengawan Solo. Yogyakarta: Indonesia Dragonfly Society.

Kurniawan P. 2018. Populasi Dan Tingkat Serangan Hama Daun Tanaman Sawi Di Bandar Lampung. [Skripsi] Bandar Lampung (ID): Fakultas Pertanian Universitas Lampung.

Lamba A, F Pasaru, Shahabuddin. 2017. Efektifitas tanaman serai (Andropogan nardus L.) sebagai tanaman penolak Liriomyza sp. (Diptera: Agromizidae) pada pertanaman bawang merah Lembah Palu. e-J. Agrotekbis 5(4): 408-414.

Pelawi AP. 2009. Indeks Keanekaragaman Jenis Serangga pada Beberapa Ekosistem Areal Perkebunan PT.Umbul Mas Wisesa Kabupaten Labuhantu. [Skripsi]. Medan (ID): Ilmu Penyakit hama dan Tumbuhan Fakultas Pertanian Universitas Sumatera Utara.

Pinem I., 2005. Beberapa Jenis Tanaman Tumpangsari Dalam Menekan Serangan Hama Liriomyza sp. Pada Tanaman Kentang (Solanum tuberosum L.). [Skripsi] Medan (ID): Universitas Sumatera Utara.

Putro SP. 2016. Konsep Aplikasi Budidaya Sistem Polikultur Terintegrasi Biomonitaring. Yogjakarta (ID): Kanisius. 
Sjam S, U Surapati, A Rosmana, S Thamrin. 2011. Teknologi pengendalian hama dalam sistem budidaya sayuran organik. J. Fitomedika 7(3): 142-144.

Tuetun B, W Choochote, Y Pongpaibul, A Junkum, D Kanjanapothi, U Chaithong, A Jitpakdi, D Riyong, B Pitasawat. 2008. Celery-based topical repellents as a potential natural alternative for personal protection against mosquitoes. Parasitol. Res. 104(1): 107-115.
Widodo J. 2007. Profil Nyamuk Aedes dan Pembasmiannya. Yogjakarta (ID): Kanisius. 